\title{
Hubungan Antara Parameter Hematologi saat Perawatan Fase Induksi dengan Kejadian Demam Neutropenia pada Anak Leukemia Limfoblastik Akut
}

\author{
Adhitya Putra Pratama, Sunartini Hapsara, Eddy Supriyadi \\ Bagian Ilmu Kesehatan Anak Fakultas Kedokteran Universitas Gadjah Mada/RSUP Dr.Sardjito, \\ Yogyakarta
}

\begin{abstract}
Latar belakang. Demam neutropenia yang terjadi, terutama fase induksi, merupakan keadaan yang mengancam jiwa serta membutuhkan penanganan yang cepat dan segera. Di RSUP Dr. Sardjito, tingkat mortalitas $11 \%$ dari $25 \%$ insiden demam neutropenia pada Leukemia Limfoblastik Akut (LLA) fase induksi. Parameter hematologi diduga berperan terhadap kejadian demam neutropenia pada anak LLA fase induksi.

Tujuan. Mengetahui hubungan antara parameter hematologi terhadap kejadian demam neutropenia anak LLA pada fase induksi.

Metode. Penelitian kasus-kontrol dengan besar sampel 100 anak. Penelitian dilakukan pada pasien yang sedang dan telah menjalani Indonesian Protocol Acute Lymphoblastic Leukemia (ALL) 2006 fase induksi, menderita demam neutropenia, dan berusia kurang dari 18 tahun. Sampel diambil secara konsekutif berdasarkan data rekam medik dan dilakukan matching berdasarkan usia, jenis kelamin, dan demam neutropenia yang terjadi pertama kali saat perawatan. Uji statistik dengan kai kuadrat dan analisis multivariat dengan regresi logistik.

Hasil. Secara statistik, hasil analisis multivariat menunjukkan monositopenia dengan jumlah monosit $\leq 100$ / $\mathrm{mm}^{3}$ dan merupakan satu-satunya variabel yang berkaitan dengan kejadian demam neutropenia, OR 3,570 ( $\mathrm{p}=0,005 ; 95 \% \mathrm{CI}=1,466-8,695)$.

Kesimpulan. Monositopenia dengan jumlah monosit $\leq 100 / \mathrm{mm}^{3}$ berhubungan dengan kejadian demam neutropenia pada anak LLA fase induksi. Sari Pediatri 2014;16(3):183-8
\end{abstract}

Kata kunci: demam neutropenia, LLA, fase induksi, parameter hematologi

\section{Alamat korespondensi:}

Dr. Adhitya Putra Pratama. Bagian Ilmu Kesehatan Anak, Fakultas Kedokteran Universitas Gadjah Mada/RSUP. Dr.Sardjito, Jalan Kesehatan No. 1 Sekip Yogyakarta 55284, Indonesia. Telp. (0274) 561616, Fax. (0274) 583745. E-mail: adhityapratama@gmx.com

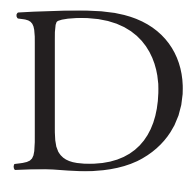

emam disertai dengan neutropenia merupakan keadaan mengancam jiwa yang membutuhkan penanganan cepat dan segera. Demam neutropenia merupakan komplikasi tersering pada pasien yang menjalani kemoterapi, terutama pada fase induksi. ${ }^{1}$ 
Luaran kematian pada leukemia limfobloastik akut (LLA) fase induksi cukup tinggi. Di RSUP Dr. Sardjito, Yogyakarta, penelitian tentang luaran Protokol Wijayakusuma-Acute Lymphoblastic Leukemia (ALL) 2000 menunjukkan bahwa laju mortalitas LLA pada fase induksi sekitar 22\%. Penurunan cukup signifikan didapatkan pada pasien LLA dengan Indonesian Protocol ALL 2006 bahwa angka mortalitasnya turun hingga $11 \% .^{2,3}$

Penelitian yang komprehensif telah dilakukan dalam menentukan faktor risiko demam neutropenia. Namun demikian, penelitian yang mengungkapkan peran parameter hematologi sebagai faktor risiko demam neutropenia pada LLA, terutama fase induksi masih sedikit, tidak tersegmentasi pada kasus LLA, dan dengan hasil yang kontroversial. Anemia dengan kadar $\mathrm{Hb} \leq 7 \mathrm{~g} / \mathrm{dL}$, trombositopenia dengan jumlah trombosit $\leq 20000 / \mathrm{mm}^{3}$, dan monositopenia dengan jumlah monosit $\leq 100 / \mathrm{mm}^{3}$ dilaporkan mempunyai kontribusi sebagai faktor risiko infeksi berat dan bakteremia pada penderita seluruh keganasan. ${ }^{4}$ Limfopenia dengan jumlah limfosit $\leq 700 / \mathrm{mm}^{3}$ berperan sebagai faktor risiko demam neutropenia pada pasien dengan tumor padat. $^{5}$

\section{Metode}

Penelitian kasus kontrol ini dilakukan di Bagian Ilmu Kesehatan Anak bangsal Hematologi-Onkologi RSUP Dr Sardjito Yogyakarta mulai tahun 2006 sampai dengan Maret 2013. Nilai Odds Ratio (OR) ditetapkan berdasarkan pada masing-masing faktor risiko demam neutropenia pada LLA selama fase induksi, yaitu anemia dengan kadar $\mathrm{Hb} \leq 7 \mathrm{~g} / \mathrm{dL}$, trombositopenia dengan jumlah trombosit $\leq 50000 /$ $\mathrm{mm}^{3}$, limfopenia dengan jumlah limfosit $\leq 700 / \mathrm{mm}^{3}$, dan monositopenia dengan jumlah monosit $\leq 100 /$ $\mathrm{mm}^{3}$. Dengan demikian, diperoleh OR pada limfosit 14,54 dengan besar sampel terbanyak dari seluruh faktor risiko yang ada. ${ }^{5}$ Penelitian ini menetapkan proporsi insiden efek pada kelompok faktor risiko $65 \%,{ }^{6}$ kesalahan tipe I 5\%, kesalahan tipe II $20 \%$, dan 50 sampel diambil secara consecutive untuk masingmasing kelompok. Kriteria inklusi adalah pasien usia 0-18 tahun yang telah didiagnosis LLA, sedang atau telah menjalani kemoterapi, catatan medis yang lengkap, dan orang tua menyatakan persetujuan untuk diikutkan dalam penelitian. Subjek dieksklusi apabila tidak masuk dalam Indonesian Protocol ALL 2006.

Data mengenai usia, jenis kelamin, parameter laboratorium, protokol kemoterapi, dan demam neutropenia saat terdiagnosis pertama kali dalam perawatan didapat dari rekam medis. Pasien dikelompokkan sebagai kelompok kasus apabila menderita demam neutropenia dan dikelompokkan sebagai kontrol apabila tidak menderita demam neutropenia. Pencocokan (matching) dilakukan terhadap usia, jenis kelamin, dan demam neutropenia yang terjadi pertama kali saat perawatan.

Demam neutropenia didefinisikan sebagai peningkatan suhu yang lebih dari $38,3^{\circ} \mathrm{C}$ dalam sekali pengukuran atau peningkatan suhu $>38^{\circ} \mathrm{C}$ dalam dua kali pengukuran yang berdekatan dalam periode 12 jam atau sedikitnya dalam 1 jam pengukuran baik pengukuran oral ataupun aksila. ${ }^{7}$

Beberapa uji statistik digunakan terhadap data yang diperoleh. Analisis univariat digunakan secara deskriptif untuk mendapatkan karakteristik dasar penelitian. Selanjutnya, data dianalisis dengan analisis bivariat dan multivariat. Analisis bivariat menggunakan kai kuadrat, sedangkan analisis multivariat menggunakan regresi logistik. Batas kemaknaan digunakan $\alpha=5 \%$, interval kepercayaan $(\mathrm{IK})=95 \%$ dan power $80 \%$.

\section{Hasil}

Selama periode penelitian didapatkan 50 sampel yang memenuhi kriteria inklusi dan eksklusi pada masing-masing kelompok. Rerata usia kasus adalah 4,85 tahun dan kontrol adalah 4,65 tahun dengan rentang usia keseluruhan adalah 3 bulan hingga 13 tahun 10 bulan.

Variabel demam memperlihatkan rerata lama demam 2,8 hari. Rentang keseluruhan lama hari demam antara 1 hingga 16 hari dengan durasi demam $<5$ hari yang dikategorikan sebesar $84 \%$. Rerata demam yang terjadi selama 7 minggu fase induksi adalah 3,02 $\pm 1,92$ minggu (Tabel 1).

Analisis bivariat dilakukan terhadap beberapa variabel parameter hematologi saat perawatan fase induksi dengan kejadian demam neutropenia pada anak dengan LLA. Hasil analisis bivariat pada masingmasing variabel tertera pada Tabel 2 .

Setelah dilakukan analisis bivariat maka dilakukan analisis multivariat terhadap semua faktor risiko 
Tabel 1. Karakteristik dasar subjek penelitian $(\mathrm{n}=100)$

\begin{tabular}{lcccc}
\hline & \multicolumn{4}{c}{$\mathrm{n}(\%)$ atau rerata \pm simpang baku } \\
\cline { 2 - 4 } Variabel & Kasus & Kontrol & Total & Nilai $\mathrm{p}^{*}$ \\
\hline Jenis kelamin & $29(29)$ & $21(21)$ & $50(50)$ & 0,110 \\
$\quad$ Laki-laki & $21(21)$ & $29(29)$ & $50(50)$ & \\
$\quad$ Perempuan & $4,85 \pm 3,36$ & $4,65 \pm 3,48$ & $4,75 \pm 3,40$ & 0,793 \\
$\quad$ Usia (tahun) & & & & \\
Demam (hari) & $42(84)$ & & $82(84)$ & \\
$\quad$ Durasi demam $\leq 5$ & $8(16)$ & & $2,80 \pm 2,71$ & \\
Durasi demam $>5$ & $2,80 \pm 2,71$ & & $3,02 \pm 1,92$ & \\
Lamanya demam (hari) & $3,02 \pm 1,92$ & & \\
Demam neutropenia saat minggu ke & & & \\
\hline
\end{tabular}
${ }^{*} \mathrm{p}<0,05$

Tabel 2. Analisis bivariat faktor berpengaruh terhadap demam neutropenia

\begin{tabular}{|c|c|c|c|c|c|c|c|}
\hline \multirow{2}{*}{ Variabel } & \multicolumn{3}{|c|}{$\mathrm{n}(\%)$} & \multirow{2}{*}{ Nilai $p^{*}$} & \multirow{2}{*}{ OR } & \multicolumn{2}{|c|}{ IK $95 \%$} \\
\hline & Kasus & Kontrol & Total & & & Terendah & Tertinggi \\
\hline \multicolumn{8}{|l|}{ Anemia $(g / d L)$} \\
\hline Kadar $\mathrm{Hb} \leq 7$ & $4 \quad(4)$ & $11(11)$ & $15(15)$ & & & & \\
\hline Kadar $\mathrm{Hb}>7$ & $46(46)$ & $39(39)$ & $85(85)$ & 0,084 & 0,348 & 0,101 & 1,195 \\
\hline \multicolumn{8}{|l|}{ Trombositopenia $\left(/ \mathrm{mm}^{3}\right)$} \\
\hline Jumlah trombosit $\leq 50000$ & $37(37)$ & $31(31)$ & $68(68)$ & & & & \\
\hline Jumlah trombosit $>50000$ & $13(13)$ & $19(19)$ & $32(32)$ & 0,280 & 1,601 & 0,680 & 3,768 \\
\hline \multicolumn{8}{|l|}{ Limfopenia $\left(/ \mathrm{mm}^{3}\right)$} \\
\hline Jumlah limfosit $\leq 700$ & $12(12)$ & $6(6)$ & $18(18)$ & & & & \\
\hline Jumlah limfosit $>700$ & $38(38)$ & $44(44)$ & $82(82)$ & 0,118 & 2,316 & 0,793 & 6,764 \\
\hline \multicolumn{8}{|l|}{ Monositopenia $\left(/ \mathrm{mm}^{3}\right)$} \\
\hline Jumlah monosit $\leq 100$ & $39(39)$ & $25(25)$ & $64(64)$ & & & & \\
\hline Jumlah monosit $>100$ & $11(11)$ & $25(25)$ & $36(36)$ & 0,006 & 3,273 & 1,372 & 7,806 \\
\hline
\end{tabular}

${ }^{*} \mathrm{p}<0,05$

Tabel 3. Hasil analisis multivariat faktor berpengaruh terhadap demam neutropenia

\begin{tabular}{lcccc}
\hline \multirow{2}{*}{ Variabel } & \multirow{2}{*}{ Nilai $\mathrm{p}^{*}$} & OR & \multicolumn{2}{c}{ IK 95\% } \\
\cline { 4 - 5 } & 0,060 & 0,293 & 0,081 & Tertinggi \\
\hline Anemia & 0,248 & 1,728 & 0,684 & 1,052 \\
Trombositopenia & 0,184 & 2,176 & 0,691 & 4,368 \\
Limfopenia & 0,005 & 3,570 & 1,466 & 6,850 \\
Monositopenia & & &
\end{tabular}

${ }^{*} \mathrm{p}<0,05$

demam neutropenia dengan menggunakan analisis regresi logistik. Variabel yang dimasukkan ke dalam analisis regresi logistik adalah variabel yang pada analisis bivariat mempunyai nilai $\mathrm{p}<0,25$, yaitu anemia, trombositopenia, limfopenia, dan monositopenia.

\section{Pembahasan}

Rerata lama demam neutropenia yang terjadi selama perawatan fase induksi, $2,80 \pm 2,71$ hari. Durasi demam neutropenia $<5$ hari merupakan lama anak dengan 
LLA menderita demam neutropenia dengan persentase $84 \%$. Awitan dan lama demam berperan penting dalam kejadian komplikasi demam neutropenia, seperti bakteremia, sepsis, dan kematian. ${ }^{8,9}$

Rerata kejadian demam neutropenia yang terjadi selama 7 minggu fase induksi adalah 3,02 $\pm 1,92$ minggu. Selama fase induksi minggu kedua hingga ketiga, terjadi penurunan sel limfosit T, sel Natural Killer (NK), dan terutama sel limfosit B. Kemungkinan terjadinya demam neutropenia antara minggu kedua dan ketiga dapat terjadi akibat penurunan imunitas alami. Namun, perlu penelitian lebih lanjut untuk membuktikan hal ini. ${ }^{10}$

Hasil penelitian ini membuktikan bahwa monositopenia, dengan jumlah monosit $<100 / \mathrm{mm}^{3}$, berkaitan dengan kejadian demam neutropenia, dengan rerata jumlah monosit $2.494 \pm 2.247 / \mathrm{mm}^{3}$. Monosit termasuk dalam golongan fagosit absolut yang berperan penting sebagai faktor prediktor kejadian infeksi, demam, dan bakteremia. ${ }^{11}$ Monosit berperan penting sebagai pertahanan awal dalam sistem imunitas tubuh serta mempresentasi patogen untuk tersensitisasi dengan sistem imunitas tubuh berikutnya sehingga dapat dipahami hubungan monositopenia sebagai faktor risiko demam neutropenia. ${ }^{12}$

Menurut literatur, peningkatan jumlah monosit dapat digunakan sebagai prediktor perbaikan neutropenia dan penanda telah terjadi perbaikan dari depresi sumsum tulang akibat perjalanan penyakit karena keganasan, kemoterapi, dan infeksi. ${ }^{11}$ Demikian pula sebaliknya, kelak di kemudian hari, jumlah monosit yang menurun secara cepat dapat digunakan sebagai prediktor untuk neutropenia berat. ${ }^{13}$ Reliabilitas pengukuran jumlah monosit termasuk cukup baik, walaupun hasil hitung jenis sel darah putih cukup rendah sehingga penggunaannya sebagai penanda neutropenia dan risiko terjadinya demam neutropenia dapat dipercaya dengan koefisien korelasi $0,785 .{ }^{11}$

Berdasarkan analisis bivariat, anemia dan trombositopenia memperlihatkan hasil yang tidak bermakna sebagai faktor risiko dan menandakan tidak berperan sebagai penyebab demam neutropenia. Terdapat dua penelitian dengan hasil yang berbeda. Penelitian pertama menyebutkan kadar $\mathrm{Hb}<7 \mathrm{~g} / \mathrm{dL}$ dan jumlah trombosit $<20000 / \mathrm{mm}^{3}$ berperan penting sebagai faktor risiko terjadinya severe infection complication (SIC), tetapi monositopenia dengan jumlah $\leq 100 / \mathrm{mm}^{3}$ bukan sebagai faktor prediktor independen terjadinya SIC. Definisi SIC adalah keadaan sepsis dan atau syok dan atau bakteremia atau fungemia yang didapat dari sampel darah dan atau kematian yang terjadi akibat proses infeksi selama proses demam neutropenia berlangsung. Dengan demikian, SIC merupakan proses infeksi berat yang terjadi selama demam neutropenia atau merupakan demam neutropenia dengan derajat berat. ${ }^{5}$ Penelitian kedua menyebutkan monositopenia dengan $<100 / \mathrm{mm}^{3}$ merupakan faktor risiko terjadinya bakteremia pada penderita demam neutropenia. ${ }^{11}$ Hasil kedua penelitian tersebut meyimpulkan bahwa monositopenia merupakan penanda awal terjadinya demam neutropenia. Sementara itu, anemia dan trombositopenia terjadi pada keadaan infeksi lanjut, yaitu bakteremia dan sepsis.

Variabel limfopenia dinyatakan tidak berhubungan terhadap kejadian demam neutropenia. Limfopenia merupakan penanda yang baik pada pasien yang mengalami toksisitas hematologi akibat kemoterapi dan peranannya sebagai faktor risiko demam neutropenia. ${ }^{6}$ Beberapa penjelasan limfopenia sebagai faktor risiko demam neutropenia tidak terbukti, ${ }^{15-17}$ seperti penelitian yang dilakukan pada jenis tumor padat dengan besar sampel yang kecil serta hanya melibatkan pada orang dewasa. Pada bagian lain, limfosit dan komponennya-sel limfosit $\mathrm{T}$ dan sel NK-mengalami titik nadir pada minggu kedua setelah dimulai kemoterapi dan meningkat kembali setelah minggu ketiga. ${ }^{10}$ Hal tersebut dapat menjelaskan mengapa limfopenia bukan sebagai faktor risiko demam neutropenia. Pada penelitian ini, penurunan limfosit terjadi bersamaan dengan demam neutropenia, yaitu antara minggu kedua dan ketiga sehingga tidak dapat dijadikan faktor risiko terjadinya demam neutropenia pada anak dengan LLA.

Beberapa penelitian mengungkapkan adanya dugaan bahwa kortikosteroid berperan terhadap limfopenia. ${ }^{6,10}$ Dalam protokol Indonesian Protocol $A L L-2006$, penggunaan kortikosteroid dibagi menjadi deksametason dan prednison. Keduanya diperlakukan secara random dalam risiko rendah dan tinggi. Steroid, bersama dengan obat kemoterapi yang lain, berfungsi untuk mengeradikasi sel blast, mencegah terjadinya resistensi kemoterapi dan gagal terapi dalam pengobatan LLA. Peran steroid begitu penting sebagai faktor prognostik LLA.,18 Namun demikian, tidak jelas diketahui bagaimana efek terapi deksametason dan prednison terhadap faktor risiko demam neutropenia. Sebuah penelitian melaporkan bahwa terapi deksametason menurunkan 
secara nyata interferon (IFN) $y^{+}$sel $\mathrm{T}$ dibandingkan prednison sehingga memicu potensi risiko infeksi dengan kerusakan pada aktivitas antimikroba. ${ }^{\mathbf{1 0 1 9}}$ Oleh karena itu, penelitian prospektif jangka panjang perlu dilakukan untuk mengetahui hubungan antara kortikosteroid dengan kejadian demam neutropenia.

Hasil penelitian ini mendapatkan monositopeniadengan jumlah monosit $\leq 100 / \mathrm{mm}^{3}$-mempunyai peranan utama terhadap kejadian demam neutropenia. Oleh sebab itu, dituntut adanya kewaspadaan dini (early warning) bagi setiap stakeholder yang terlibat dalam perawatan anak dengan LLA. Tindakan preventif perlu dilakukan dalam rangka mencegah terjadinya demam neutropenia. Faktor risiko lain yang diduga berpengaruh terhadap parameter hematologi dengan kejadian demam neutropenia-seperti sitokin tertentu, yaitu IL-5, 6 dan 8, jenis antibiotik, dan biakan kuman-juga perlu dianalisis.

Penelitian ini memiliki beberapa kelemahan, di antaranya tidak adanya interpersonal observer yang memantau hasil pemeriksaan hematologi, terapi antibiotik, dan penggunaan kortikosteroid yang tidak diikutkan sebagai bagian yang diteliti sehingga dapat menjadi perancu (confounding).

\section{Kesimpulan}

Monositopenia dengan jumlah monosit $\leq 100 / \mathrm{mm}^{3}$ berhubungan dengan kejadian demam neutropenia pada anak LLA fase induksi.

\section{Daftar pustaka}

1. Lyman GH, Rolston K. How we treat febrile neutropenia in patients receiving cancer chemotherapy. J Oncol Pract 2010;6:149-52.

2. Widjajanto PH, Supriyadi E, Purwanto I, Sutaryo $S$. Dexamethasone versus prednisone in childhood acute lymphoblastic leukemia treatment:results of the Indonesian randomized trial. unpublished 2012;92108.

3. Widjajanto PH, Sutaryo S, Purwanto I, Ven PM, Veerman PJ. Early response to dexamethasone as prognostic factor: result from Indonesian childhood WK-ALL protocol in Yogyakarta. J Oncol 2012;2012:1-8.

4. Rondinelli PI, Ribeiro KC, de CB. A proposed score for predicting severe infection complications in children with chemotherapy-induced febrile neutropenia. J Pediatr Hematol Oncol 2006;28:665-70.

5. Oguz A, Karadeniz C, Ckitak EC, Cil V. Which one is a risk factor for chemotherapy-induced febrile neutropenia in childhood solid tumors: early lymphopenia or monocytopenia? Pediatr Hematol Oncol 2006;23:14351.

6. Donadieu J, Auclerc MF, Baruchel A, Hill C. Prognostic study of continuous variables (white blood cell count, peripheral blast cell count, haemoglobin level, platelet count and age) in childhood acute lymphoblastic leukaemia. Analysis Of a population of 1545 children treated by the French Acute Lymphoblastic Leukaemia Group (FRALLE). Br J Cancer 2000;83:1617-22.

7. Lyman GH, Lyman CH, Agboola O. Risk models for predicting chemotherapy-induced neutropenia. Oncologist 2005;10:427-37.

8. Basu SK, Fernandez ID, Fisher SG, Asselin BL, Lyman GH. Length of stay and mortality associated with febrile neutropenia among children with cancer. J Clin Oncol 2005;23:7958-66.

9. Santolaya ME, Alvarez AM, Becker A, Zubieta M. Prospective, multicenter evaluation of risk factors associated with invasive bacterial infection in children with cancer, neutropenia, and fever. J Clin Oncol 2001;19:3415-21

10. Eyrich M, Wiegering V, Lim A, Schrauder A, Winkler $B$, Schlegel PG. Immune function in children under chemotherapy for standard risk acute lymphoblastic leukaemia - a prospective study of 20 paediatric patients. Br J Haematol 2009;147:360-70.

11. Klaassen RJ, Goodman TR, Pham B, Doyle JJ. "Lowrisk" prediction rule for pediatric oncology patients presenting with fever and neutropenia. J Clin Oncol 2000; 18:1012-9.

12. Acha-Orbea H, Berg L; Cancro M, Zwickey H. Basic concepts in immunology. Dalam Murphy K, Travers P, dan Walport M, penyunting. Janeway's immunobiology. New York: Garland Science;2008.h.1-27.

13. Kondo M, Oshita F, Kato Y, Yamada K, Nomura I, Noda K. Early monocytopenia after chemotherapy as a risk factor for neutropenia. Am J Clin Oncol 1999;22:1035 .

14. Rackoff WR, Gonin R, Robinson C, Kreissman SG, Breitfeld PB. Predicting the risk of bacteremia in childen with fever and neutropenia. J Clin Oncol 1996;14:91924.

15. Blay JY, Chauvin F, Le CA, Biron P. Early lymphopenia 
after cytotoxic chemotherapy as a risk factor for febrile neutropenia. J Clin Oncol 1996;14:636-43.

16. Choi CW, Sung HJ, Park KH, Kim JS. Early lymphopenia as a risk factor for chemotherapy-induced febrile neutropenia. Am J Hematol 2003;73:263-6.

17. Ray-Coquard I, Borg C, Bachelot T, Blay JY. Baseline and early lymphopenia predict for the risk of febrile neutropenia after chemotherapy. $\mathrm{Br} \mathrm{J}$ Cancer 2003;88:181-6.
18. Yetgin S, Cetin M. The dose related effect of steroids on blast reduction rate and event free survival in children with acute lymphoblastic leukemia. Leuk.Lymphoma 2003;44:489-95.

19. Safdar A, Rodriguez GH, Lichtiger B, Champlin RE. Recombinant interferon gamma1b immune enhancement in 20 patients with hematologic malignancies and systemic opportunistic infections treated with donor granulocyte transfusions. Cancer 2006;106:2664-71. 